\title{
After-Sales Services and Consumers' Perception of Quality: A Study of Refrigerator Users (Consumers) in South East Nigeria
}

\author{
OKO, A. E. NDU \\ Senior Lecturer of Marketing, Abia State University, Uturu, Nigeria \\ E-mail: a.e_nduoko@yahoo.com
}

Tel: $234-805-785-1630$ or $234-806-486-8940$

Onuoha A. Onuoha

Department of Marketing, University of Port Harcourt, Nigeria

Received: August 9, 2013 Accepted: September 6, 2013 Published: November 6, 2013

doi:10.5296/bmh.v1i2.4516 URL: http://dx.doi.org/10.5296/bmh.v1i2.4516

\begin{abstract}
Even well designed, defect-free products can fail if they do not fit consumers' perceptions of high quality or if appropriate follow-up service is unavailable. Poor however is that some products that command high customer favourable perception with high turnover do not always turn out to be profitable. The objective of the study, therefore, is to ascertain the impact of after-sales services on consumers' perception of quality and corporate turnover and profitability. One hundred and twenty (120) consumer and vendor (manufacturers) respondents from each of the major commercial cities of the five (5) states of South East Nigeria were conveniently selected for study. Data generated from the respondents using a set of questionnaire, were analyzed using statistical tools. The results showed, among others, that after-sales services impact positively on consumers' perception of quality loyalty, however little on turnover and corporate profitability. Based on the findings of the study, the research concludes that there is still room for growth in after sales services and customer loyalty management as many marketers and product managers, especially in household appliances market, have not fully grasped and made use of the whole potential of after-sales service and the strategic importance of the management of customer loyalty for corporate profitability given the inputs of after sales services. The research thus, recommends, among others, that firms should ensure that customer service is an integral part of the product offering, to be subjected to the same quality standards as the production process, adopt good pricing strategy and monitor customer behaviour for profit maximization among others.
\end{abstract}


Keywords: after sales service, consumers' perception, quality, refrigerator, South East Nigeria 


\section{Introduction}

Quality, even across different horizontal and vertical levels of authority is differently assessed. Management most often considers quality in terms of cheaper alternatives that are capable of fulfilling the same function. From the engineers' and technicians' view point, quality is based on specifications and descriptions. Thus technical considerations take precedence over all other considerations. Given the gap existing between the assessment of quality vis-a vis management and the engineers and technicians, the role of policy in buying as guide to the activities of the buying centre is important, especially as it is difficult to match technical specifications of items with availability of desired items and at an affordable price.

Quality as rightness of purchase is determined by balancing technical considerations against such economic factors as price and availability-Lysons (1981), Fajemilua (1997) and Oko (2013). While corporate effort at the determination of quality is influenced by product description, standardization and specification as guided by corporate policies, the natural consumers measure quality based on perception as products are exposed for attention and interpretation made concerning the offer-Hawkins, Best and Coney (2001), in terms of affordability, availability, serviceability; durability, scrap value, multiplicity of purpose of usage, pre and post sales test, reputation of vendor, after sales services among others.

Corporate executives and consumers have in recent years adopted divergent views of product quality. Several recent studies, such as Berndt (2009); Cronin, Brady and Hult (2000); Erasmus and Gothan (2008); and Martinez and Martinez (2010), indicate how wide the quality perception gap is. Mindful of this gap, many companies have turned to promotional tactics to improve and showcase the quality of their products and image. Such efforts are evident in two trends. The first is the greater emphasis advertisements place on the word quality and on such themes as reliability, durability, and workmanship. The second trend is the move to quality assurance and extended service programmes-Takeuchi and Queich, (1983).

While these attempts to change customer perceptions are steps in the right direction, a company's or a product's quality image obviously cannot be improved upon overnight. It takes time to cultivate customer confidence, and promotional tactics alone will not do the job -Takeuchi and Queich, (1983). In fact, they can backfire if the claims and promises projected do not hold up and customers perceive them as gimmicks.

To ensure delivery of advertising claims, companies must build quality into their products (goods or services). From a production perspective, this means a company's wide commitment to eliminate errors at every stage of the product development process-product design, process design, and manufacturing. It also means working closely with suppliers to eliminate defects from all incoming parts.

Equally important, yet overlooked, are the marketing aspects of quality-improvement programmes. In support of this, Inyanga (2001), states that firms that will satisfy their various customer needs best and make the most profits should be marketing organizations in theory and practices. Thus, companies must be sure they are offering the benefits customers seek. 
Quality should be primarily customer-driven, not technology-driven, production-driven, or competitor-driven -Takeuchi and Queich, (1983).

In developing product quality programmes, companies often fail to take into consideration, certain basic questions such as- Viardot (2010) and Tekeuchi and Quelch (1983):

i. How do customers define quality?

ii. How important is high quality in customer service, and how can high quality be ensured after-sale?

iii. Do after-sales services have strong impact on customers' perception of quality?

iv. Is after-sales service part of product's Brand Promise"?

v. Can reliable and robust after-sales services increase the acceptance rate of a new product from the same firm?

Providing answers to these questions, as well as essential information on how to build an effective customer-driven quality programme, for profit maximization is the main thrust of this paper.

\section{Theoretical Foundation}

Household appliances are relatively expensive commodities and entail short and long-term financial consequences that most consumers may find difficult to deal with in terms of household budgets especially in the developing economy of Nigeria. Appliances are durable products and are expected to be operational for a considerable period of time. They also represent complex product category because relevant technology changes continually. Most consumers consequently find it difficult to keep up with; and fully grasp modifications to product categories Erasmus, (2010). In addition, the ownership of an appliance may even signify the status of the owner and that may affect the product and brand purchasedNieftagodien and Van der Berg (2007). The acquisition of major household appliances is therefore regarded as high-risk involving and may create a considerable amount of uncertainty and anxiety - even more so for inexperienced consumers-Buttle (2004) and Beatty, Mayer, Coleman, Raynolds and Lee (1996). Thus selecting a brand of a particular household-appliance, with quality, is one of the major decisions of the buying process of household appliances, including refrigerators.

Hence, vendors and other agents adopt the use of after sales services to stabilize the buying decision processes and post purchase disposition of customers. After sales services as product support activities are product-centric transactions needed to uncover customer needs as they are strategically used as drives for retention-Peterson and Balasubramanian (2002), Vitasek (2005), Simmons (20001), Goffin and New (2001), Agnihotrin, Sivasubramanian and Simmons (2002) and Gallagher, Mitchke and Roger (2005).

Generally, the after sales service components of an offer play vital role in influencing consumer perception of the offer; thus bridge the gap between consumer expectations and perceptions-Pereira, Ferreira, Carvalho and Rotonadaro (2009), and Fazlzadeh, 
Bagherzadah and Mohamadi (2011), motivate loyalty and turnover. These are expected to enhance corporate profitability.

\section{Objectives of the Study}

Most households unlike most corporate bodies do not have funds to commit to regular replacement of appliances, equipment and technologies of operations, especially given the expensive nature of these commodities and their financial consequences as well as the poor (low) level of per capita income in Nigeria. Even in the face of these constraints, manufacturers and vendors of the appliances must make sales commendable with reasonable profit margin to remain in business. This work thus, has the objective of ascertaining the positive or otherwise relationship between after sales services and consumer perception of quality through the optimization of the satisfaction and desires of consumers based on the manipulation of post sales services by manufacturers and vendors of appliances, equipment and technologies, as quality driven device for corporate goal (profit) actualization.

\section{Significance of the Study}

It is difficult to measure objectively the quality of services unlike that of goods - Crosby (1970) and Garvin (1983), as services quality is abstract and elusive in construct as it is built around the characteristics of intangibility, heterogeneity and inseparability of production and consumption-Parasuranman, Zeithaml and Berry (1985). In attempt at measuring quality in the absence of objective yardsticks, Parasuraman, Zeithaml and Berry (1988) measure consumers' perception of the quality of firm's services without however appropriate measures for gauging consumers' perception. This work describes the development of a multiple-item scale for measuring service quality (SERVQUAL) as it also disclose the scale's properties and potential application, thus recommends after sales services as basis for competitor performance evaluation; inter and intra (departmental) organizational performance evaluation; as it reveals key attributes that facilitate or hinder the delivery of high quality services, for market segmentation according to demographic, psychographic and/ or other profiles, for influencing consumer service quality perceptions and for unvailing reasons behind ascertained perceptions, among others, as run ways to enhance corporate turnover and profitability.

In the work of Fazlzadeh, Baghereadeh and Mohamadi (2011), the effect of after sales services on customers' satisfaction as well as on customers' behavioural intention were investigated with particular reference to repurchase intentions and word of mouth communication among customers. This work shows that after-sales services quality affect satisfaction as well as the consumer behavioural intentions as they affect corporate offering and the quality of corporate relationship with target market.

Contributing to the discourse on after sales services and quality, Mivegerano, Kankanranla, Hameenoja and Suominen (2012), consider after sales services as competitive tool along the service chain, thus reveals that after sales services resolve cases of product failure within the service chain and reduce or eliminate cases of time wasting, as additional information about issues are provided, thus perception of quality is high as well as customer satisfaction, and 
Pereira, Ferreira, Carvalho and Rotondaro (2009), did study on the service chain and compared the perception of quality by the middlemen with client. Analyses shows that middlemen in their relationship with manufacturers (as principal /vendors) have reliability as index of quality while quality from the clients point of view is based on courtesy.

In these work above, non-studied the impact of after sales services on perception as an index of quality and as means of securing consumer loyalty with its cumulative effect on turnover and profit as basis of measuring shareholders' welfare. This difference as gap is the thrust of the exercise.

To this end, the result of this exercise will aid manufacturers and vendors of refrigerators and other equipment and appliances as technologies of household and corporate operations reposition their market offer for competitive advantage based on the integration of after-sales services as components of the market offer. It will as well aid marketers enhance consumer satisfaction given their offer as a means of ensuring increase turnover and profit and the reduction in the rate and level of shift in brand of electronics by products consumers.

\section{Research Hypothesis}

The study is anchored on a single null hypothesis stated thus:

H0: After-sales services do not significantly influence consumers' perception and loyalty and vendors' turnover and profitability in the refrigerator market in South East Nigeria.

\section{Literature Relevant to the Study}

Product quality is the product's ability to fulfill the expectations and needs set by the end user. This is supported by the Encyclopedia of Engineering (2002), which states that product quality is the collection of features and characteristics of a product that contribute to its ability to meet given requirements.

To understand how the larger market perceives quality, most firms collect much information directly from customers. Even with such information, pinpointing what customers really want is not a simple task. For one thing, consumers cannot always articulate their quality requirements - Takeuchi and Queich (1983). They often speak in generalities, complaining about several things.

The quality of an offer is determined by balancing technical considerations against such economic factors as price and availability-Oko (2013). While price is an explicit variable, availability is implicit, and part of the service component of the offer.

Quality is thus variously discussed, based on the description by actual sample, reference to brand name or trade mark, reference to established market grade and the use of detailed specification or blue print-Fajemilua (1997). These description options are mostly environmentally influenced, thus the consumers' perception of quality defer.

Consumers' priorities and perceptions also change over time. Taking automobiles as an example, market data compiled by SRI International suggest that consumer priorities shifted from styling in 1990 to fuel economy in 1995 and then to quality of design and performance 
in 2000-McEachron and Javitz (2004).

Based on the above, Rust and Oliver (1994) assert that service quality has three broad sub-dimensions; the personnel related, the tangible offering related and the service scape related.

Services as complimentary or supplementary along the chain of distribution enhance the quality of market offer technically, hence the value the customer receives either for satisfaction and or beyond for delight-Fazlzadeh, Bagherzndeh and Mohamadi (2011). Services also influence the methods, strategies and policies on which products are delivered. Thus, services are central in an offer, playing central or core role as functional utility source. Based on this, services play functional and or delivery roles-Rust and Oliver (1994).

Services that accompany goods (products) to the point of purchase are generally considered paid for by the consumers; hence they have influence on the product price. Beyond the point of purchase, services are classified as after sales. Thus after sales services are referred to as product support activities, point of contact with consumers after purchases and as events or programmes whose impact significantly influence consumer perception of the offer as well as consumer loyalty to corporate brand-Lele (1997), Gallaher, Mitchke and Rogers (2005) and Alexander, Dayal, Dempsey and Vander Ark (2002). These after sales services add to the reputation or quality of the vendor and the market offer.

Ability to influence the perception of the consumer positively on the quality of corporate offer is measured based on some components of after sales services of reliability, responsiveness, competence, accessibility, courtesy, communication, credibility, security, tangibility and understanding of the customer as attributes of the product, complementary services and service providers-Paraasuraman, Zeithaml and Berry (1988).

Perceived quality as the customers' perception of the overall quality or superiority of a product or service with intended purpose relative to alternative-Miregorago, Kankaaranta, Harmeenoja and Suominon (2012) and Kasper, H. and Lemmink, J. (1989) is considered important to the vendor, as the index of evaluation of loyalty and repeat purchases, however, customers differ in their perceptual ability, personal judgements, and experience, thus quality as an assessment index varies-Kasper and Lammink (1989), according to product, relative to competing products. This assertion is supported by a remark credited to John E. Welch, Chairman and Chief Executive of General Electric Company thus: The customer rates us better or worse than somebody else. It's not very scientific but it's disastrous if you score low -Welch (2001). The management of customers' remarks concerning corporate offer lies on the management of the quality of the offer through the management of associated services, especially after sales services.

\subsection{Service Quality, Product and Market Differentiation}

In the assertion of Parasuraman, Zeuthaml and Berry (1988), service quality assessment serves as predicator of consumer satisfaction based on its usefulness in predicting target market expectations and perceptions. It is also vital for assessment of trend of growth in the market. Based on this assertion, quality differentiates market offer from competitors' offer, 
hence it forms basis for market segmentation, personnel and quota allocation as well as employee performance evaluation.

The evaluation of the quality of an offer is based on the evaluation of product's accompanying services. It is therefore important to note that the manipulation of the after sales services component of an offer with good quality blending of the promotion inter and intra elements creates meaningful responses of consumers to the offer, thus influences target market perception for the offer.

Marketing based on after sales services characteristics of reliability; consistency assurance of the ability of the offer to create delight, tangibility compared to the explicit value of the offer as well as responsiveness and courtesy traits of personnel assure quality of products-Mivegerano, Kankaranta, Hameenoja and Suominer (2012) and Fazlzadeh, Bagherzadeh and Mohamadi (2011).

Quality of an offer as projected in the after sales services if well examined based on the attributes of the offer that influence consumers' expectations and perception is able to unveil factors that inhibit consumer loyalty and market turnover, thus it forms basis of proactive actions for the delivery of high quality services-Berry (1996). This, as a salient service quality dimensional activity has its target as consumer satisfaction enhancement, as it affords the organization the opportunity of comparing its offers with those of competitors in strengths and weaknesses - Parasuraman, Zeuthaml and Berry (1988). It is the opinion of authorities in marketing that after sales services evaluation draws management's attention to the need to enhance the qualities of offer-Pereira, Ferreira, Carvalho and Rotanaro (2009); Mvagerano, Kankaaranta, Zeuthaml and Berry (1988) and Fazlzadeh, Bagherzacheh and Mohamdi (2011).

\subsection{After Sales Services, Turnover and Corporate Profitability}

Profit is the positive differential between marginal revenue and marginal cost. After sales service is considered a major source of corporate profitability as well as the major index of performance evaluation of organizations - Uise and Baumgartner (1997). Accepted is the fact that profit associated with after sales services is greater than that generated based on sales and sales activities from the point of product display to point of sales-Levitt (1983), hence after sales services secure consumer loyalty, enhanced turnover based on enhanced consumer satisfaction; though, not in all cases as loyalty requires a deeper experience with the product brand-Rudy (2013) These account for the estimated revenue generated on services of four or five times compared to revenue associated with the physical (tangible) product - Bundschuh and Dezvane (2003). Stressing the obvious, Wise and Baumgartner (1992), value turnover revenue generated based on after sales services at, at least three times compared to those associated with the purchase of the core, augment and symbolic product pre-and or at the point of sales.

To ensure enhanced corporate profitability therefore, organizations are expected to invest on after sales services as catalyst for enhanced word of mouth communication among satisfied consumers, for improved consumer perception, loyalty and turnover. 
Though Reinartz and Kumer (2002), in their study found a weak correlation between loyalty and profitability, Pnoyson (2012), traces a strong correlation between loyalty and profitability and associates this strong correlation to the fact that:

- Loyal customers cost less to serve,

- Loyal customers are willing to pay more than other customers and

- Loyal customers act as word of mouth marketers for different organizations.

Balancing the differences in opinion between Reinartz and Kumar (2002) and Baysen (2012), on customer loyalty and profitability-Keinghem, Aksoy, Buoye and Williams (2012), assert that loyal customers are those who devote a larger share of their wallet to a company, and do recommend corporate offer to friends, thus loyalty is a drive to profitability.

After sales services thus should aim at spurring the customer to actions of favorable disposition to corporate offer rather than being bound to the organization only. This is because mere knowledge of the customers' feelings about the organization is not considered an adequate predictor of the behvaiour of the customers toward an organization's market offer-Keiningham, Aksoy, Buyoe and Williams (2012). Loyal customer may not be profitable until the loyalty is motivated to favorable disposition to offer by the expectation of delight, especially those built on after sales services-Oko (2013) and Keiningham, Aksoy, Buye and Williams (2012).

\subsection{Satisfied Consumer in Word of Mouth Communication}

Satisfied consumers based on quality offer anchored on after sales services develop action based on favourable disposition toward corporate offer, thus share information with other individuals, hence serve as critical influence on consumer decisions and business success - Herr, Kardes and Kim (1991). The use of word of mouth communication varies by product category and with target market demographic variables-Hawkins, Best and Coney (2001). It is important to note that consumer evaluation of product as purchase decision is based on information available concerning the product, price and performance-Hunt and Keaveney (1994), but is more based on satisfaction of previous users of the product concerning the service component of the product-Spreng, Mackenzie and Olshavkey (1996).

The study by Keavency (1995), lists core service failure, service encounter failures, pricing, inconvenience, response to service failures, attraction by competition, ethical problems and involuntary switch as reasons for consumer service switch out. Of these, consumers have particularly negative reactions to delays in delivery and service failure-Taylor (1994), Taylor and Claxton (1996), Hui and Tse (1996), Hui, Dube and Chebal (1996), Hui, Thakor and Tam, Burns and Zeng (1997). Cushioning the effect of these service and service related failures requires customization and personalization of customer contacts that are also considered expensive-Mittel and Lassar (1996), Sprong and Mackey (1996), Sirohi, MeClaughlin and Wittork (1998) and Bearden, Melhotra and Uscategic (1996). Consumer dis-satisfaction based on service failure is also managed based on the provision of guarantee 
and warrantee services. These services, it is agreed increase expected performance levels and patronage; however they also increase the cost of service and have negative impact on corporate profit-McDougell, Lavesgue and Vander (1998) and Ostrom and Lacobucci (1998). Swan and Cumbs (1976), assert that dis-satisfaction is caused by a failure of instrumental performance, while complete satisfaction also requires the symbolic functions to be performed at or above the expected levels. These symbolic functions include creation of good quality (favourable) perception of market offer, communicated based on the system of word of mouth.

Word of mouth communication is informal, interactive, swift and may not have commercial value, however it influences consumer behaviour greatly-Fazlzadeh, Bagherzadeh, and Mohamadi (2011). Heskett, Jones Loveman, Sasser and Schlesinger (1995), consider word of mouth communication as component in a satisfaction-profit framework as such a functional rather than dys-functional perception of service quality, hence vendors and manufacturers as vital members of the chain of marketing must introduce services considered qualitative for enhanced perceived overall service quantity and perceived service value-Danaher and Rust (1996), Fullerton and Taylor (2002), Hartline and Jones (1996), Sweeney and Soutar (2001) and Fazlzadeh, Bagherzadeh and Mohamadi (2011).

\subsection{After-Sales Services, Its Cost Implications, Quality and Customer Perception}

After sales services have great cost implication, even at this, consumers are demanding high quality at low prices. This is in consonance with a study, by Abrams (2001), of a national panel of shoppers on where it would like to see food manufacturers invest more, as the highest-rated response was "better quality for the same price".

Quality, therefore is a key source of product differentiation among firms in the market place and gives competitive advantages to organizations that are highly quality conscious-Inyanga, (2001) and Parasuraman, Zethmel and Berry (1988). It incorporates the organization's ability to meet the specific needs and requirements, such as delivery on time of exactly the right quality, packaged appropriately, among others. It is therefore not a concern of the product only but a wholesome system of doing things in an organization-Inyanga (2001), including service to customers before, during and after a purchase -Micah, (2010).

Customer services, according to Turban (2002), are series of activities designed to enhance the level of customer satisfaction, that is, the feeling that a product or service has met the customers' expectation. It is also an acceptable performance for the quality of service that a firm expects to deliver to its customers, and can often be explained with respect to delivery and availability of product-Ogwo, (2011).

From the point of view of an overall sales process engineering effort, customer service plays an important role in an organization's ability to make income and revenue -Selden, (1998). From that perceptive, customer services should be included as part of an overall approach to systematic success. Customer service experience can change the entire perception a customer has of the organization-Micah, (2010). Product performance and customer service are closely linked in any quality programme; the greater the attention to product quality in 
production, the fewer the demand on the customer service operation to correct subsequent problems. Besides its usual functions, customer service can act as an early warning system to detect product quality problems. Customer surveys measuring product performance can also help spot quality control or design difficulties; and of course detecting defects early, spares later embarrassment and headaches -Takeuchi and Queich,(1983).

The quality of customer service after the sale is often as important as the quality of the product itself - Rust, Danaher and Varki (2000). A vast majority of high tech firms managed to grow successfully during the recent economic downturn by developing their after-sales services. In high technology sector, more than any other industry, after-sales activity is very often a highly-profitable business - Vardot (2010), but has great cost implication associated there-to it. After-sales services include not only the customers' claim and warranty management, but also the maintenance operations, the spare parts planning and logistics, and all the operations with a lasting effect on customers' satisfaction-Viardot, 2004; Erasmus, (2010). For firms that have a Gillette "razor and blade" marketing strategy, after-sale product and service cannot be considered independently of the product in terms of market share and profitability, because while the product is used to enter the market, the money is made on the spare parts-Viardot, (2004).

Whitney, Dayal and Vender Ark (2002), in a study of the car industry, show that General Motors Corporation indicated that the company made more profit with its $\$ 9$ billion after-sales than with its direct $\$ 150$ billion car sales. This is in line with the result of a study by McClusky (2002) on AMR Company, which indicates that the company's after-sales service represents an average $24 \%$ of revenue but generates an astounding $45 \%$ of profit. This share of revenues can be even higher as in the case of Rolls-Royce Plc, where after-sales represented $55 \%$ of overall turnover in 2004-Viardot, (2010). In business-to-business transaction, after-sales services can generate three to four times the turnover of the original purchase during the solution's lifecycle-Viardot, (2010). Snecma and Bombardier, companies in the aircraft engines and spare parts businesses, report after-sales as representing $80 \%$ of the net present value versus $20 \%$ for original equipment. Interestingly, the opposite effect for aircraft occurs. Airbus' after-sales account only for $30 \%$ of the net present value versus $70 \%$ for new equipment—Bundschuh and Dezvane, (2003).

For consumer products, it can be estimated that after-sales services can generate between $20-30 \%$ of total sales, if correctly managed. The bulk of the margin does not come from the direct repairs but from spare parts whose margin can be more than $50 \%$, and support and warranty contracts whose margin may be above $75 \%$. There is still room for growth as many marketers and product managers have not fully grasped and made use of the whole potential of after-sales service. The way forward, according to Viardot (2010), is first by segmenting the after-sales market according to customers' needs, and second by designing the correct service offer.

Various companies, such as Dell, Lexmark, Raytheon and Agilent have conducted research on the needs and expectations of their customers regarding after-sales services. All the surveys demonstrate that although price is important to customers, the key issues are 
swiftness of delivery, reliability, and availability of repair and maintenance services - Viardot, (2010).

The beauty of after-sales services, according to Whitney Dayel and Vendder Ark (2002), is that they can double profit margin compared to the profitability of the goods sold, especially in an environment that is economically depressed like Nigeria. But this is limited by the inability of firms to create favourable balance between the marginal cost of operation (implicit and explicit) and actual and or anticipated marginal revenue. This work is interested in the management of the cost implications of after sales services as factor of quality of offer and catalyst to customer favourable perception, loyalty and turnover and corporate profitability.

\section{Scope and Methodology}

This study is focused on users of refrigerators in Aba, Onitsha, Owerri, Enugu and Abakaliki. This scope is informed by the fact that these towns have major electronic markets and especially for Aba with three major concentrated electronics markets at Ekeoha, Orie Ohabiam and Ariaria, as well as a refrigerator manufacturing firm at Eziama.

Brands of refrigerators abound in the Nigerian market. These brands include Haier Thermocool, LG Samsung, Sharp, Super National, Royal, Scanfrost, Restpoint, Nexus, Sonoko, among others. However, the study is limited to Haier Thermocool owing to the fact that Haier-Peterson Zochonis (HPZ) Ltd, makers of the brand, has Depots and service centres nationwide, including $\mathrm{Aba}$, and other named towns.

A total sample size of 120 Management staff, vendors and consumer-respondents from each of the major commercial cities of the five South East states of Nigeria service centres of HPZ Ltd. were used. This management staff, vendors and consumer-respondents were either buying Haier Thermocool or having their previous purchased ones serviced or served the needs of buyers in sales or and maintenance and repairs.

All the elements in the sample size were selected judgmentally. Thus, the selections of the elements that constitute the sample were based on the researchers' presumption that those elements would be representatives of the population of study - Ezejelue, Ogwo and Nkamnebe (2008).

Data collected in the course of the study, through self-administered copies of questionnaire, were analyzed using statistical tools such as tables and percentages pearson correlation co-efficient ' $R$ ' for the measurement of relationships for strength or weakness of association between variables - Ezejelue, Ogwo and Nkamnebe (2008) and Likert's five (5) scale ranking order-Fubura and Muguni (1995). The analysis largely depended on responses from the copies of questionnaire administered to the manufactures and customers of services of HPZ Ltd in these areas as scope of the study as well as depth interviewers.

\section{Decision rule as basic of interpretation of findings is}

Accept projected statement: If and only if the value calculated is greater than the accepted mean value of $50 \%$ (Fifty percent). 


\section{Macrothink}

Reject Projected Statement: If otherwise.

\section{Data Presentation and Analysis}

In this section, the work analyzed the data collected in the course of the study, for the purpose creating meaning; a total of 600 copies of structured questionnaire were distributed at 120 copies to each of the five major commercial cities of the five states of South East Nigeria. Out of these, $84(70 \%), 90(75 \%), 76(63 \%), 82(68 \%)$ and $91(75 \%)$ of the copies of questionnaire retrieved from Aba, Enugu, Onitsha, Abakaliki and Owerri respectively totaling $423(70.5 \%)$ and were found useful and qualitative to form basis for the research analysis. This $70.5 \%$ returned (valid) copies of questionnaire is considered high enough to depend on for valid expression of opinion.

Table 1. Assessment of the attributes of quality of after sales services

\begin{tabular}{|c|c|c|c|c|c|c|c|c|c|c|}
\hline \multirow{2}{*}{$\begin{array}{l}\text { Analysis of } \\
\text { Attribute of } \\
\text { Service }\end{array}$} & \multicolumn{5}{|c|}{$\begin{array}{l}\text { Assessment of Manufacturers by } \\
\text { Vendors }\end{array}$} & \multicolumn{5}{|c|}{$\begin{array}{l}\text { Assessment of Vendors by } \\
\text { Consumers }\end{array}$} \\
\hline & 5 & 4 & 3 & 2 & 1 & 5 & 4 & 3 & 2 & 1 \\
\hline Tangibles & 5 & 2 & 2 & 1 & $\varnothing$ & 4 & 2 & 2 & 2 & 0 \\
\hline Reliability & 4 & 2 & 2 & 2 & $\varnothing$ & 5 & 2 & $\varnothing$ & 2 & 1 \\
\hline Responsiveness & 3 & 3 & 2 & 1 & 1 & 4 & 2 & 3 & 1 & $\varnothing$ \\
\hline Assurance & 4 & 1 & 2 & 2 & 1 & 5 & 2 & 2 & 1 & $\varnothing$ \\
\hline Empathy & 3 & 3 & 2 & 1 & 1 & 4 & 3 & 2 & 1 & $\varnothing$ \\
\hline Total Score & 19 & 11 & 10 & 7 & 3 & 22 & 11 & 9 & 7 & 1 \\
\hline Multiplier & 5 & 4 & 3 & 2 & 1 & 5 & 4 & 3 & 2 & 1 \\
\hline Weighted score & 95 & 44 & 30 & 14 & 3 & 110 & 44 & 27 & 14 & 1 \\
\hline Aggregate & 186 & & & & & 196 & & & & \\
\hline Weighted score & & & & & & & & & & \\
\hline
\end{tabular}

Based on values in Table 1

\begin{tabular}{lll}
\hline Standard weight & 250 & 250 \\
\hline Actual weight & 186 & 196 \\
\hline Actual weight as percentage of Standard & $74.4 \%$ & $78.4 \%$ \\
\hline
\end{tabular}

\section{Interpretation}

Vendors(as channel members) assessed the attributes of quality of services received from manufacturers at $74.4 \%$, while consumers assessed vendors, based on the same criteria at $78.4 \%$.

Based on the above, the quality of services associated with the marketing of Haier Thermocool Brand of refrigerator considered at $74.4 \%$ and $78.4 \%$ for manufacturers and vendors respectively are above $50 \%$, as accepted mean value. 


\section{Mll Macrothink}

Business and Management Horizons

ISSN 2326-0297

2013, Vol. 1, No. 2

\section{Conclusion}

The quality of after sales services contributes significantly to the marketing of Haier Thermocool refrigerators in South East Nigeria.

Table 2. Assessment of the impact of after sales services on perception

\begin{tabular}{|c|c|c|c|c|c|c|c|c|c|c|}
\hline \multirow[t]{2}{*}{ Attributes } & \multicolumn{5}{|c|}{$\begin{array}{l}\text { Assessment of } \\
\text { Manufacturers by Vendors }\end{array}$} & \multicolumn{5}{|c|}{$\begin{array}{l}\text { Assessment of Vendors by } \\
\text { Consumers }\end{array}$} \\
\hline & 5 & 4 & 3 & 2 & 1 & 5 & 4 & 3 & 2 & 1 \\
\hline $\begin{array}{l}\text { Time it takes to respond to } \\
\text { complaint (product failure) }\end{array}$ & 3 & 3 & 2 & 1 & 1 & 4 & 3 & 2 & 1 & $\varnothing$ \\
\hline $\begin{array}{l}\text { Applicability of policy } \\
\text { on warranty }\end{array}$ & 4 & 3 & 2 & 1 & 1 & 4 & 4 & 2 & $\varnothing$ & $\varnothing$ \\
\hline $\begin{array}{l}\text { Influence of friends/ and } \\
\text { as opinion leaders }\end{array}$ & 4 & 4 & 1 & 0 & $\varnothing$ & 5 & 4 & 1 & $\varnothing$ & $\varnothing$ \\
\hline $\begin{array}{l}\text { Satisfaction over time } \\
\text { (experience of the service } \\
\text { component of the offer) }\end{array}$ & 3 & 3 & 3 & 1 & $\varnothing$ & 3 & 3 & 2 & 1 & 1 \\
\hline $\begin{array}{l}\text { Service of effectiveness } \\
\text { compared to competitors }\end{array}$ & 4 & 3 & 0 & 2 & 1 & 4 & 4 & 1 & 0 & 1 \\
\hline Total Score & 18 & 16 & 8 & 5 & 3 & 20 & 18 & 8 & 2 & 2 \\
\hline Multiplier & 5 & 4 & 3 & 2 & 1 & 5 & 4 & 3 & 2 & 1 \\
\hline Weighted score & 90 & 64 & 24 & 10 & 3 & 100 & 72 & 24 & 4 & 2 \\
\hline Aggregate Weighted score & 191 & & & & & 202 & & & & \\
\hline
\end{tabular}

Based on values in Table 2

\begin{tabular}{lll}
\hline Standard weight & 250 & 250 \\
Actual weight & 191 & 202 \\
Actual weight as percentage of Standard & $76.4 \%$ & $80.8 \%$ \\
\hline
\end{tabular}

\section{Interpretation}

Vendors' assessment of the impact of manufacturers' after sales services on their perception of products quality and those of customers on vendors is show as $76.4 \%$ and $80.8 \%$ respectively. These scores are above the mean value of $50 \%$, thus are considered high.

\section{Conclusion}

The perception of consumers (as ultimate or intermediate) on the quality of Haier Thermocool refrigerators is significantly influenced by the quality of after sales services. 
Table 3. Assessment of after sales services on customer loyalty

\begin{tabular}{|c|c|c|c|c|c|c|c|c|c|c|}
\hline \multirow[t]{2}{*}{ Assessment variables } & \multicolumn{5}{|c|}{$\begin{array}{l}\text { Assessment of } \\
\text { Manufacturers by } \\
\text { Vendors }\end{array}$} & \multicolumn{3}{|c|}{$\begin{array}{l}\text { Assessment of } \\
\text { by Consumers }\end{array}$} & \multicolumn{2}{|c|}{ Vendors } \\
\hline & 5 & 4 & 3 & 2 & 1 & 5 & 4 & 3 & 2 & 1 \\
\hline Cost of serving loyal customers & 3 & 2 & 3 & 1 & 1 & 2 & 2 & 2 & 2 & 2 \\
\hline $\begin{array}{l}\text { Willingness of loyal customer to pay } \\
\text { more }\end{array}$ & 2 & 2 & 2 & 2 & 2 & 3 & 2 & 3 & 2 & $\varnothing$ \\
\hline $\begin{array}{l}\text { Loyal customers' involvement in } \\
\text { word of mouth communication }\end{array}$ & 3 & 2 & 2 & 1 & 2 & 4 & 3 & 2 & 1 & $\varnothing$ \\
\hline $\begin{array}{l}\text { Loyal customers' contribution to } \\
\text { profit }\end{array}$ & 2 & 2 & 3 & 2 & $\varnothing$ & 2 & 2 & 2 & 1 & 3 \\
\hline $\begin{array}{l}\text { Loyal customers' likelihood to show } \\
\text { both attitudinal and behavioural } \\
\text { responses }\end{array}$ & 2 & 2 & 2 & 2 & 2 & 2 & 2 & 3 & 1 & 2 \\
\hline Total Score & 12 & 10 & 12 & 8 & 8 & 13 & 11 & 12 & 7 & 7 \\
\hline Multiplier & 5 & 4 & 3 & 2 & 1 & 5 & 4 & 3 & 2 & 1 \\
\hline Weighted score & 60 & 40 & 36 & 16 & 8 & 65 & 44 & 36 & 14 & 7 \\
\hline Aggregate Weighted score & 160 & & & & & 166 & & & & \\
\hline
\end{tabular}

Based on values in Table 3

\begin{tabular}{lll}
\hline Standard weight & 250 & 250 \\
Actual weight & 160 & 166 \\
Actual weight as percentage of Standard & $64.0 \%$ & $66.4 \%$ \\
\hline
\end{tabular}

\section{Interpretation}

Assessment of impact of after sales services on customer loyalty shows $64.0 \%$ and $66.4 \%$ for manufacturers and vendors respectively. These are relatively high compared to the mean value of $50 \%$

\section{Conclusion}

After sales services create in customers; the behaviour of loyalty. 


\section{Macrothink}

Business and Management Horizons

ISSN 2326-0297

2013, Vol. 1, No. 2

Table 4. Assessment of impact of after sales services on customers' perception and customer loyalty on turnover

\begin{tabular}{|c|c|c|c|c|c|c|c|c|c|c|}
\hline \multirow[t]{2}{*}{ Measurement Variables } & \multicolumn{5}{|c|}{$\begin{array}{l}\text { Evaluation by } \\
\text { Manufacturers }\end{array}$} & \multicolumn{5}{|c|}{$\begin{array}{l}\text { Evaluation by } \\
\text { Vendors }\end{array}$} \\
\hline & 5 & 4 & 3 & 2 & 1 & 5 & 4 & 3 & 2 & 1 \\
\hline $\begin{array}{l}\text { Impact of after sales services on } \\
\text { turnover }\end{array}$ & 4 & 3 & 2 & $\varnothing$ & 1 & 4 & 3 & 2 & 1 & $\varnothing$ \\
\hline $\begin{array}{l}\text { Impact of customers' loyalty on } \\
\text { turnover }\end{array}$ & 3 & 3 & 2 & 2 & $\varnothing$ & 3 & 4 & 2 & $\varnothing$ & 1 \\
\hline $\begin{array}{l}\text { Impact of customers' perception on } \\
\text { turnover }\end{array}$ & 3 & 3 & 1 & 2 & 1 & 3 & 3 & 3 & 1 & $\varnothing$ \\
\hline $\begin{array}{l}\text { Impact of word of } \\
\text { communication on turnover }\end{array}$ & 3 & 3 & $\varnothing$ & 2 & 2 & 4 & 2 & 1 & 3 & $\varnothing$ \\
\hline $\begin{array}{l}\text { Impact of the reaction and attitude of } \\
\text { channel members on turnover }\end{array}$ & 2 & 2 & 1 & 2 & 3 & 2 & 2 & 2 & 2 & 2 \\
\hline Total Score & 15 & 14 & 6 & 8 & 7 & 16 & 14 & 10 & 7 & 3 \\
\hline Multiplier & 5 & 4 & 3 & 2 & 1 & 5 & 4 & 3 & 2 & 1 \\
\hline Weighted score & 75 & 56 & 18 & 16 & 7 & 80 & 56 & 30 & 14 & 3 \\
\hline Aggregate Weighted score & 173 & & & & & 183 & & & & \\
\hline
\end{tabular}

Based on values in Table 4

\begin{tabular}{lll}
\hline Standard weight & 250 & 250 \\
Actual weight & 173 & 183 \\
Actual weight as percentage of Standard & $69.2 \%$ & $73.2 \%$ \\
\hline
\end{tabular}

\section{Interpretation}

Manufacturers' (plant managements') and vendors' assessment of after sales services, customers' perception, loyalty among others on corporate turnover shows $69.2 \%$ and $73.2 \%$ respectively. These indicate high and significant impact, as percentage scores are reasonably high above $50 \%$, the accepted mean values.

\section{Conclusion}

After sales services, customers' perception and loyalty, word of mouth communication and channel members' opinions and re-action influence turnover significantly. 
Table 5. Assessment of the impact of after sales services, customers' perception and loyalty and turnover on corporate profitability

\begin{tabular}{llllllllllll}
\hline Assessment Variables & \multicolumn{3}{l}{$\begin{array}{l}\text { Manufacturing (Assembly } \\
\text { plant) }\end{array}$} & \multicolumn{7}{c}{ Vendors } \\
& 5 & 4 & 3 & 2 & 1 & 5 & 4 & 3 & 2 & 1 \\
\hline After sales services on & 1 & 2 & 1 & 4 & 2 & 1 & 2 & 2 & 2 & 3 \\
profitability & & & & & & & & & & \\
Loyalty on profitability & 2 & 1 & 3 & 3 & 1 & $\varnothing$ & 2 & 2 & 1 & 5 \\
Perception on profitability & 1 & 2 & 2 & 3 & 2 & 0 & 2 & 2 & 4 & 2 \\
Turnover on profitability & 0 & 1 & 2 & 3 & 2 & 1 & 2 & 1 & 2 & 4 \\
Total Score & 4 & 6 & 8 & 13 & 9 & 2 & 8 & 7 & 9 & 14 \\
Multiplier & 5 & 4 & 3 & 2 & 1 & 5 & 4 & 3 & 2 & 1 \\
Weighted score & 15 & 24 & 24 & 26 & 9 & 10 & 32 & 21 & 18 & 14 \\
Aggregate Weighted score & 98 & & & & & 95 & & & \\
\hline
\end{tabular}

Based on Table 5 values

\begin{tabular}{lll}
\hline Standard weight & 200 & 200 \\
Actual weight & 98 & 95 \\
Actual weight as percentage of Standard & $49.0 \%$ & $47.5 \%$ \\
\hline
\end{tabular}

\section{Interpretation}

Based on the analysis above, the impact of after sales services, customers' perception and loyalty as well as turnover on profitability is $49.0 \%$ and $47.5 \%$ respectively for manufacturing plants and vendors. These percentages are below (however not significantly) the research accepted mean value of $50 \%$.

\section{Conclusion}

After sales services, customers' perception and loyalty and turnover do not influence corporate profitability significantly.

Based on the analyses on tables 1, 2, 3, 4 and 5 the hypothesis of this research; after sales services do not significantly influence consumers' perception and loyalty and vendors' turnover and profitability in the refrigeration market in South East Nigeria is rejected with limitation. The limitation is that after sales services, influences consumers' perception and loyalty and vendors' turnover but do corporate profitability insignificantly.

Table 6 is adopted to prove co-relation or otherwise between the assessments of manufacturers and vendors and consumers on various variables of test. 


\section{Macrothink}

Business and Management Horizons

ISSN 2326-0297

2013, Vol. 1, No. 2

Table 6. Determination of correlation between the assessments of assembly plants and those of vendors as presented on tables 1,2,3,4 and 5

\begin{tabular}{lll}
\hline Basis of Assessment & Manufacturers & Vendors \\
\hline $\begin{array}{l}\text { Attributes of quality of after sales services } \\
\text { Impact of after sales services on customer }\end{array}$ & 74.4 & 78.4 \\
perception & 76.4 & 80.8 \\
$\begin{array}{l}\text { Impact of after sales services on customer } \\
\text { loyalty }\end{array}$ & 64.0 & 66.4 \\
$\begin{array}{l}\text { Impact of after sales services, customer } \\
\text { perception and loyalty on turnover }\end{array}$ & 69.2 & 73.20 \\
$\begin{array}{l}\text { Impact of after sales services, customer } \\
\text { perception, loyalty and turnover on profitability }\end{array}$ & 49.0 & \\
\hline
\end{tabular}

Based on the mathematical notation:

$$
\mathrm{r}_{\mathrm{xy}=} \frac{\sum(x-0)(y-\sigma)}{n_{S_{x}} S_{y}}
$$

Where: $x$ and $y$ are each values of $x$ and $y$

0 and $\sigma$ are mean values of $\mathrm{x}$ and $\mathrm{y}$

$\mathrm{s}_{\mathrm{n}}$ and $\mathrm{s}_{\mathrm{y}}$ are standard deviation of $\mathrm{x}$ and $\mathrm{y}$

$\mathrm{n}$ is the number of paired values

Let ' $x$ ' represent manufacturers assessment of vendors and associated variables of the study and ' $\mathrm{x}$ ', vendors assessment of customers/ consumers and associated variables of the study.

Based on values in table 6 and substituting for mathematical notation 1

$$
\mathrm{r}_{\mathrm{xy}}=\frac{\sum(x-0)(y-\sigma)}{n^{n} S_{x} S_{y}}=\frac{(266.4)(.27 .04)}{5(132.2)(138.52)}=\frac{73803.456}{91561.72}=0.8060
$$

Based on the computation, a correlation of 0.80 is established. This shows a positive correlation between data generalized from the management of Haier Thermocool refrigerators plants in the South East Nigeria and those of their various vendors and service consumers on issues of quality of after sales services, consumers' perception and loyalty and manufacturers' and vendors' turnover and profitability. Thus after sales services influence customers' perception of quality and loyalty as well as vendors' turnover but not profitability. 


\section{Findings}

The findings of this work include:

- Vendors and Haier Thermocool refrigerator service consumers (customers) affirmed that price is not the only influencing factor in their preference for this brand of refrigerators. This may not be unconnected with the fact that Haier Thermocool refrigerator are considered more costly than most other brands of refrigerators in the Nigeria market.

- The quality of Haier Thermocool refrigerators, especially as associated with after sales services as non-price variable is considered a vital is influencing variable of vendors' and consumers' (customers') perception and loyalty as well as turnover for the product.

- Analysis show that after sales services greatly influence vendors' and consumers' perception for Haier Thermocool refrigerators, however this perception does not create as much impact on consumer loyalty for the product; as perception of vendors and consumers (customers) were $76.4 \%$ and $80.8 \%$ and loyalty $64 \%$ and $66.4 \%$ respectively. See tables 2 and 3.

- Loyalty for the product is considered low compared to perception, but turnover is considered higher than loyalty-at $69.2 \%$ and $73.2 \%$ for vendors and service consumers respectively.

- It was also discerned that the combined effect of after sales services, customer perception and loyalty, increased the turnover of the product, the profit margins of the assembly plants (manufacturers) of Haier Thermocool refrigerators as well as those of the vendors were not significantly increased. See table 5

- The Haier Thermocool refrigerator (Assembling plants) management and vendors in assessing the impact of various variables of after sales services on target markets perception, loyalty, turnover and profitability have a high degree of correlationship of 0.8060. This shows that these variables have almost equal impact on their various (respective) operational efficiency.

- Word of mouth communication plays vital role in the marketing of Haier Thermocool refrigerators.

- Generally, it is believed that favourable customers' perception leads to loyalty and to enhanced corporate turnover and profitability. This is tenable only given good quality management of customer loyalty. Vendors' assessing that manufacturers and customers' assessment of vendors on the attributes of after sales (based on Likert's ranking scale in table 1) that influenced the perception of quality most favourably, for Haier Thermocool refrigerators; valued attributes of tangibles, reliability, responsiveness, assurance and empathy high. This was considered based on the report obtained as some households and corporate customers and users of this brand of refrigerators were interviewed in Aba, Umuahia, Owerri, Enugu and Abakaliki in the course of the research field survey. 


\section{Discussion of Findings}

- Users of Haier Thermocool refrigerators depend on vendors as vendors depend on management of the various assembly plants. This dependency relationship is/was sustained based on after sales services that anchor on tangibles (physical facilities, equipment and appearance of personnel); reliability (ability of the product to perform the promised service dependably and accurately), responsiveness (willingness to help customers and provide prompt services); assurance (knowledge and courtesy of employees and their ability to inspire trust and confidence on the vendors by the assembly plants and on the product service consumers (customers) by the vendors) and empathy (as the caring trait of personnel, and individualized attention the firm and vendors at various levels of contact provide for customers).

These as well as the warranty policies of the firm show the importance of good response and repair time respectively as factors in creating quality which have ultimately led to customer retention - Nwegerano, Kankaarante, Hameenoja and Suominen (2012). These services as either point of sales activity based and or post sales services that are quality based, especially along the supply chain are significantly factor influences for corporate overall competitiveness - Cohan, Agrawel and Agrawel (2006).

- It should be appreciated that the time taken for corrective activities given customers' dissatisfaction due to product failure along the supply chain has significant impact on perception of quality hence, influence loyalty-Nwegerano, Kankaarante, Hameenoja and Suominen (2012), hence vendors in these relationships with customers and manufacturing plant management in their relationship with vendors are expected to align relevant actions within the service chain to meet the expectations of the target market - Cohen, Agrawel and Agrawel (2006), with particular regards to optimizing the attributes of the offer and corporate reputation-Oko (2002).

Efforts of marketing chain members at enhancing target markets perception of quality of offer given warranty policies especially based on corrective actions as means of resolving cases of product failure must be time shortened.

- The quality of after sales services enhances customer satisfaction, perception and loyalty, thus offers competitive advantage as it forms basis for market segmentation. This is assured as customers are persuaded to place subjective value on different aspects of corporate offer. Satisfied customers are motivated attitudinally and behaviourly, however, more attitudinally. This accounts for the decline in customer loyalty compared to perception, and profitability compared to turnover. See tables 2 and 3 and tables 4 and 5 respectively.

- Findings of this work show a weak correlationship between customer perception and loyalty, and corporate turnover and profitability. Perception and loyalty were at $76.4 \%$ and $80.8 \%$; and $64 \%$ and $66.4 \%$ for manufacturing plants and vendors respectively. Manufacturing plant and vendors' turnover and profitability were at $69.2 \%$ and $73.2 \%$, and $49 \%$ and $47.5 \%$ respectively. Decline in customer perception over loyalty were at $16.3 \%$ and 
$17.8 \%$ for manufacturers and vendors but corporate (plant) and vendors turnover and profit declined at $29.1 \%$ and $54.1 \%$ respectively. See tables 4 and 5 respectively.

This shows that good product perception does not always ensure loyalty neither does turnover guarantee profitability. It is therefore important for firms to note that creating and nurturing real customer loyalty requires satisfying customers' needs and wants at a sustainable profit-Kerningham, Aksoy, Buoye and Williams (2012), especially as loyalty does not always mean profit.

- The ability to convert loyalty to profitability (in the face of customers' good quality perception of corporate good quality service) is the index of corporate success. It is important to note that firms assess loyalty in terms of those who devote greater fraction of their net income to acquisition of corporate offer and are more willing to be involved actively in recommending corporate market offer to friends, hence aid the organization in its profit drive. This is relatively correct, however loyalty as a relationship should necessitate a positive shopping action/behaviour by the customer; not necessarily by or based on the expectations of greater (deals) rewards.

Customers of the Haier Thermocool refrigerators especially at the vendor level are mostly firms operating in the straight Rebuy (task) class principles. Having acquired adequate information about the product in an unchanging market environment, maximize their market advantage based on their value for Haier Thermocool refrigerator plant as they demand premium services and or price discount-Boysen (2012). These vendors in their relationship with the manufacturing plants demand lower prices especially on logistics of product transfers and storage and warehousing and material handling. These off set savings the company could have generated-Boysen (2012), Keiningham, Aksoy, Buoye and Williams (2012) and Reimartz and Kumar (2002). Based on these, loyal customers are more costly to serve. These costs incidences affect profit.

Loyal customers are more price elasticity sensitive, thus resist attempts at price increase. They develop platforms to exploit vendors (manufacturers). Thus their loyalty is attitudinal rather than behavioural, willing to tell others about the quality and availability of an offer but not willing to patronize the offer at a price that will generate profit to the vendors and manufacturers. It is thus expected that manufacturers as well as vendors of Haier Thermocool refrigerators should target customers who are not only loyal both in attitude and action behaviour but are also profitable—Keiningham, Aksoy, Buoye and Williams (2012).

\section{Managerial Implication of the Findings}

Manufacturers of household appliances should take note of consumers' apparent ignorance when purchasing complex products. From the viewpoint of the discipline of Customer Science, the ideal, according to Erasmus (2010), would be for retailers to accept the challenge and that they gain competitiveness in the marketplace through a more altruistic approach that is to assist and support consumers, rather than abiding with economic marketing principles. Newman and Cullen (2002) advice that, in order to survive in a competitive environment and to surpass competitors, a firm has to provide much more than considered sufficient. 
According to the findings of this study, product quality may be based on elements of after-sales service offerings that are neglected at present by most firms. The efforts of most firms are focused on product, price and elements of promotion, which may result in "sameness" that fail to elevate individual firms' service offerings. After-sales services have a strong impact on consumers' satisfaction and consequently on the repurchase rate of a product because a customer who is experiencing a problem with an after-sales product will tend to switch to another product. It is proper to conclude that after sales services have strong impact on consumers' perception of quality product. In developing product quality programmes, most companies often fail to take into account some basic sets of questions like, how do customers define quality, how important is high quality in customer service and how can high quality be ensured after the sale? Among others.

As mundane as these questions may sound, Takeuchi and Queich (1983) opine that the answers provide essential information on how to build an effective customer -driven quality programme. It is the belief of this work that there is still room for growth in after-sales services as many marketers and product managers, especially in the household appliances market, have not fully grasped and made use of the whole potential of after-sale services. This could be done first by segmenting the after-sales service market according to customers' needs and secondly by designing the correct service offer. This will form basis for customer loyalty evaluation and management for enhanced corporate profitability.

Marketers and product managers should not forget that customers, after all, serve as the ultimate judge of quality in the marketplace. In support of the foregoing, Daghani, Nasr and Khanbeigi (2011) assert that "senior management and individuals' (within the organizations) understanding of the concept of productivity and quality is best understood by understanding the customers".

\section{Conclusion}

After sales services enhance customers' perception of the quality of Haier Thermocool refrigerators, hence customer loyalty is considered high. This however does not show a corresponding high level of profitability, even when turnover is high. It is therefore important that appropriate steps be adopted in the management of the organisations' loyal customers especially as profitable customers constitute only $18 \%$ of the organizations' customers.

\section{Recommendations}

This work recommends as follows:

- After sales services, as quality enhancing tool and market segmentation basis are relevant in customer loyalty satisfaction. Loyalty among customers will yield profit where loyalty influences attitude and behaviour (action) and the marginal difference between the sales revenue generated and the cost of serving the customers is adjudged high in favour of the organization especially as the organization is able to maximize the goals of improving loyalty and her financial performance. 
- Firms having identified its market and assessed the quality of its after sales services as well as the core and symbolic product, could enter the market based on skimming pricing policy (strategy) or penetrating pricing policy (strategy); for revenue and profit optimization.

In addition to the above, these are vital:

- Firms in the household appliances industry should ensure that customer service is not an after thought but an integral part of the product offering and is subject to the same quality standards as the production process.

- Firms should consistently conduct research on the needs and expectations of their customers with regard to after-sales services. Customers' feedback from such study should be used to increase corporate service levels, thereby staying one step ahead of competition.

- After-sale solutions must be designed and marketed to keep out competitors through third-party maintenance specialists or customers' in-house maintenance units. This is because switching costs and convenient alternatives also have strong influence on the value perceived by customers.

- Because the after-sales units may be perceived as a competitor by the distribution channels-direct or indirect, it must not overlap with sales when dealing with customers so as to avoid confusion and conflicts.

- Product managers and marketers should know their customers' expectations for after-sales product and services and should deliver a proposal that matches the customers' expectations, in terms of delivery, reliability, availability and price.

- There is more than just the delivery of after-sales services, thus it is important for product managers to be involved in the definition of after-sales services. In doing so, product managers and marketers should ensure full exploitation of complete potential of the after sales market for their product in order to achieve more market power, market share, and profitability.

- Good understanding of the behaviour of the organizations' set of loyal customers is important for strategy and policy building and development as customers are stratified (segmented) accordingly into attitudinal, behavioural and attitudinal and behavioural bases. This will influence the value of resources the organization will expend on each category of loyal customers - Reinartz and Kumar (2002) Clark (2006).

- It should be noted that profitable loyal customers referred to as true believers are not difficult to satisfy within existing corporate policies. They tend to return goods at relatively high rate, evidencing their high level of comfort in doing business with the vendor. They are often steady and regular in patronage but may not buy in large quality. They have favouable attitudinal and behavioural disposition towards the vendor, thus need to be encouraged possibly based on least cost contacts of mails, text messages and periodic greetings as well as price promotion, invitation to conferences and other corporate marketing events. These exercises have reasonable impacts on true believers purchasing behaviour in volume and value, thus accelerate corporate profitability. 
- The second groups of loyal customers are transient in nature; they seek to make profit on all purchases made given their ascribed value, rather than build sustainable relationship with a particular vendor. Investing to retain this class of loyal customers often achieves less than desired results, thus managers are advised to make best out of them while they are still customers. Hence strategies advocated for their management include short term hard sell activities based on intensive promotion and direct mails that make special offers.

- The third groups of loyal customers are often considered most problematic. The level at which their generated returns on investments is very low compared to cost of maintaining them, especially as value and volume of transaction is considered too low. Management of this group of loyal customers may be best by identifying their problem and solving same at least possible cost. In the Haier Thermocool refrigerators marketing, the problematic customers abound as they constitute major third party agents who earn a living as they introduce buyers to the product.

- Firms must device strategies of creating and sustaining favourable relationship between customer satisfaction and customer loyalty based on good quality after sales services especially as customer satisfaction does not always result in customer loyalty. Loyalty requires a deeper experience with particular product brand. Therefore organizations that desire to achieve reliable customer loyalty must be involved in purposeful management of customer emotional bond. It is therefore recommended that organizations should align and re-align their policies, processes and delivery mechanisms with customer values, as this is the antidote to profitability.

Firms are also required to be involved in quality choice of customer segments and offer the right touch points and the right key performance indicators as means to customer loyalty and profitability especially as sustainable loyalty is only achieved based on sustainable customer centric culture, based on providing the right mix of training, empowerment and influencer-based leadership that has the ability of sharpening customer focus of the toughest corporate culture-Randy (2013), Kumar, Shah and Venketesan (2006).

\section{References}

Agnihothri, S., Sivasubramanisn, N., \& Simmons, D. (2002). Leveraging Technology to Improve Field Service. Int. J. Sarv. Ind Manage, 13(1), 47-68. http://dx.doi.org/10.1108/09564230210421155

Bearden, W. O., Malhotra, M. K., \& Uscategui, K. H. (1998). Consumer Contact and the Evaluation of Service Experiences. Psychology and Marketing, December, 793-289. http://dx.doi.org/10.1002/(SICI)1520-6793(199812)15:8<793::AID-MAR5>3.0.CO;2-0

Beatty, S. E., Mayer, M., Coleman, J. E., Reynolds, K. E., \& Lee, J. (1996). Customer-sales Associate Retail Relationships. Journal of Retailing, 72(3), 223-247. http://dx.doi.org/10.1016/S0022-4359(96)90028-7

Berndt, A. (2009). Investigation Service Quality Dimensions in South African Motor Vehicle Servicing. African Journal of Servicing Management, 1(1), 1-9. 
Bundschuh, R. G., \& Dezvane, T. M. (2003). How to Make After-sales Services Pay Off. The McKinsey Quarterly.

Buttle, F. (2004). Customer Relationship Management: Concept and Tools. Oxford: Elsevier Butterworth-Heinemann.

Cohen, J. J., \& Taylor, S. A. (1992). Measuring Service Quality-A Reexamination and Extension. Journal of Marketing, 56, 55-68. http://dx.doi.org/10.2307/1252296

Cronin, J. J., Brady, M. K., \& Hult, G. T. M. (2000). Assessing the Effects of Quality, Value and Customer Satisfaction on Consumer Behavioural Intentions in Service Environments. Journal of Retailing, 2(76), 193-218. http://dx.doi.org/10.1016/S0022-4359(00)00028-2

Daghani, R., Nasr, M., \& Khanbeigi, M. A. (2011). Productivity, New Paradigm for Management, Accountant and Business Environment. International Journal of Business and Management, 6(6), 247-262. http://dx.doi.org/10.5539/ijbm.v6n6p247

Encyclopedia of Engineering. (2002). Product Quality. Retrieved April 16, 2012, from www.encyclopedia2.thefrredictionary.com

Erasmus, A. C. (2010). Customer Service in Appliance Sales Department of Selected Prominent Retail Outlets: Store Manager, Sales Personnel and Customer Perspectives. Journal of Family and Consumer Sciences, 38, 30-42.

Erasmus, A. C., \& Gothan, A. J. (2008). Customers' Judgment of the Customer Service in Retrieved April 16, 2012, from www.mendeley.com/research/customers

Ezejelue, A. C., Ogwo, E. O., \& Nkamnebe, A. D. (2008). Basic Principles in Managing Research Projects (2nd ed.). Aba: Afritower Limited.

Fazlzadeh, A., Bagherzadeh, F., \& Mohamadi, P. (2011). How After-Sales Services Quality Dimensions Affect Customer Satisfaction. African Journal of Business Management 5(17), 7658-7664.

Gallagher, T., Milchke, M. D., \& Rogers, M. C. (2005). Profiting from Spare Parts. McKinsey Q.

Goffin, K. (1999). Customer Support A Cross - industrial Study of Distribution Channels and Strategies. Int .J Physical Distribution, Logistics Management, 29(6), 374-97. http://dx.doi.org/10.1108/09600039910283604

Hawkins, D. I., Best, R. J; \& Coney, K. A. (2001). Consumer Behaviour Building Marketing Strategy. Boston: Irwin McGraw-Hill.

Herr, P. M., Kardes, F. R., \& Kim, J. (1991). Effects of Word of Mouth and Product-Attributes Information on Persuasion. Journal of Consumer Research, 454-467. http://dx.doi.org/10.1086/208570

Hui, M. K., \&Tse, D. K. (1969). What to Tell Consumers in Waits of Different Lengths. Journal of Marketing, April, 81-90. 
Hui, M. K., Duba \& Chebat, J. C. (1997). The Impact of Music on Consumers' Reactions to Waiting for Services. Journal of Retailing, 87-104.

Hui, M. K., Thakor, M. V., \& Gill, R. (1998). The Effects of Delay Type and Service State on Consumers' Reaction to Waiting. Journal of Consumer Research, March, 469-479. http://dx.doi.org/10.1086/209522

Hunt, K. A., \& Keaveny, S. M. (1994). A Process Model of the Effects of Price Promotions on Brand Image. Psychology and Marketing, November, 511-532. http://dx.doi.org/10.1002/mar.4220110602

Inyanga, J. (2001). Total Quality Management (TQM) and the Growth of Nigerian Marketing Organization. Journal of Business and Finance, 1(4), 93-103.

Kasper, H., \& Lemmink, J. (1989). After Sales Services Quality Views Between Industrial Customers and Service Managers. Industrial Marketing Management, 18, 199-208. http://dx.doi.org/10.1016/0019-8501(89)90036-9

Keaveney, S. M. (1995). Customer Switching behaving in Service Industries: An Exploratory Study. J. Mark, 59(2), 71-82. http://dx.doi.org/10.2307/1252074

Keaveney, S. M. (1995). Determinants of Satisfaction. Journal of Marketing, April, 71-82. http://dx.doi.org/10.2307/1252074

Kumar, P., La.Wani, M. U., \& Dada, M. (1997). The Impact of Waiting Time Guaranties on Customers' Waiting Experiences. Marketing Science, 295-314. http://dx.doi.org/10.1287/mksc.16.4.295

Kumar, V., Shah, D., \& Venkatesan, R. (2006). Managing Retailer Profitability-One Customer at a time.

MacDougall, G. H. G., Levesque, T., \& Vander, P. (1998). Designing the Service Guarantees. Journal of Service Marketing, 78-293.

Martinez, J. A., \& Martinez, L. (2010). Some Insights on Conceptualizing and Measuring Service Quarterly. Journal of Retailing and Consumer Services, 17, 29-42. http://dx.doi.org/10.1016/j.jretconser.2009.09.002

McClusky, M. (2002). Service Lifecycle Management: The Approaches and Technologies to Build Sustainable Advantages for Services. AMR Research, August.

McEachron, N. B., \& Javitz, H. S. (2004). Managing Quarterly: A Strategic Perceptive. SRI International Business Intelligence Programme Report.

Micah, S. (2010). Seven Key to Building Customer Loyalty and Company profits. Retrieved April 14, 2012, from http://www.fastcompany.com/article/seven-keys-to-building-customer-loyalty-and-companyprofits? Page $=0 \% 2 \mathrm{co}$.

Mittel, B., \& Lassar, W. M. (1996). The Role of Personalization in Service Encounters. 
Journal of Retailing, 95-104. http://dx.doi.org/10.1016/S0022-4359(96)90007-X

Mwegerano, A., Kankaaranta, J., Hameenoja, O., \& Suominen, A. (2012). Perceived After Sales Services Quality: Communication within the Service Chain. Quality Technology of Quantitative Management, 9(4), 407-419.

Newman, A. J., \& Cullen, P. (2002). Retailing: Environment and Operations. London: Thomson Learning.

Niftagodien, S., \& Van Der Berg, S. (2007). Consumption Patterns and the Black Middle Class: The Role of Assets. Bureau of Economic Research, 2(7), 1-10.

Ogwo, E. O. (2011). Lecture Note on Marketing Logistics Management. ABSU.

Oko, A. E. NDU. (2002). Marketing Research, Issues, Concepts and Strategies. Enugu, Skinno Prints.

Oko, A. E. NDU. (2013). Industrial Marketing: Contending with Environmental Challenges. Nigeria, Keyholders \& Associates.

Ostrom, A. M., \& Lacobucci, D. (1998). The Effect of Guarantees on Consumers Evaluation of Services. Journal of Service Marketing, 362-78. http://dx.doi.org/10.1108/08876049810235405

Parasuraman, A., Zeithaml, V., \& Berry, L. (1985). A Conceptual Model of Service Quality and Its Implication for Future Research. Journal of Marketing, Fall, 41-50. http://dx.doi.org/10.2307/1251430

Parasuraman, A., Zeithaml, V., \& Berry, L. (1988). SERVQUAL: A Multiple-Item Scale for Measuring Consumer Perceptions of Service Quality. Journal of Retailing, 64(1).

Peterson, R. A., \& Balasubramanian, S. (2003). Retailing in the 21st Century Reflections and Prologue to Research. J. Retail, $\quad 78(1)$, 9-16. http://dx.doi.org/10.1016/S0022-4359(01)00062-8

Rudy, V. (2013). Increase Profitability through Customer Loyalty. Retrieved from rudyvidal.net/cop-content/plugins/download-monitor/download.php?-20/07/2013.

Rust, R. T., Danaher, P. J., \& Varki, S. (2000). Using Service Quality Data for Comparative Marketing Decisions. International Journal of Service Industry, 5(11), 438-451. http://dx.doi.org/10.1108/09564230010360173

Selden, P. H. (1998). Sales Process Engineering: An Emerging Quality Application. Quality Progress, 7, 59-63.

Simmons, D. E. (1977). Breaking Free from Product Marketing. J. Mark, 41(2), 73-80. http://dx.doi.org/10.2307/1250637

Sirohi, N., McClaughhin, E. W., \& Wittink, D. R. (1998). A Model of Consumer Perception and Store Loyalty, Intentions for a Supermarket Retailer. Journal of Retailing, 233-45. 
Spreng, R. A., Mackenzie, S. M., \& Olshavsky, R. W. (1996). A Reexamination of the Determination of Consumers Satisfaction. Journal of Marketing, July, 15-32. http://dx.doi.org/10.2307/1251839

Stayman, D. M., \& Deslpande, R. (1989). Situational Ethnicity and Consumer Behaviour. Journal of Commercial Research, December, 361-371.

Swan, I. E., \& Combs, L. J. (1976). Product Performance and Consumer Satisfaction: A New Concept. Journal of Marketing, April, 25-33. http://dx.doi.org/10.2307/1251003

Takeuchi, H., \& Quelch, J. A. (1983). Quality is More than Making a Good Product. Harvard Business Review, 83(4), 139-145.

Taylor, S. (1994). Waiting for Service. Journal of Marketing, April, 56-69. http://dx.doi.org/10.2307/1252269

Taylor, S. (1995). The Effects of Filled Waiting Time and Service. Journal of the Academy of Marketing Science, Winter, 38-48. http://dx.doi.org/10.1007/BF02894610

Taylor, S., \& Claxton, J. D. (1994). Delays and the Dynamics of Service Encounters. Journal of the Academy of Marketing Science, Summer, 258-264.

Tom, G., Burns, M., \& Zeng, Y. (1997). Your Life on Hold. Journal of Direct Marketing, 25-31. http://dx.doi.org/10.1002/(SICI)1522-7138(199722)11:3<25::AID-DIR5>3.0.CO;2-Z

Turban, E. (2002). Electronic Commerce: A Managerial Perspective. New York: Prentice-Hall, Inc.

Viardot, E. (2004). Successful Marketing Strategies for High Tech Firms (3rd ed.). Boston: ArtechHouse.

Viardot, E. (2010). Exploiting the Full Potential of After-sales Markets. Retrieved April 14, 2012, from www.pragmaticmarketing.com

Vitasek, K. (2005). Supply Chain and Logistics Terms and Glossary.

Welch, J. E. (2001). Where Is Marketing Now That We Really Need It? A Speech Presented at 2001 Marketing Conference, New York City, October 28.

Whitney, L. A. S; Dayal, J. J. D., \& Vander Ark, J. D. (2002). The Secret Life of Factory Service Centres. The McKinsey Quarterly, 106-116.

\section{Copyright Disclaimer}

Copyright reserved by the author(s).

This article is an open-access article distributed under the terms and conditions of the Creative Commons Attribution license (http://creativecommons.org/licenses/by/3.0/). 